\title{
The Potential of Cooperative Integrated Reading and Composition in Biology Learning at Higher Education
}

\author{
Rizhal Hendi Ristanto ${ }^{1}$, Siti Zubaidah ${ }^{2}$, Mohamad Amin ${ }^{2}$, Fatchur Rohman ${ }^{2}$
}

\begin{tabular}{l} 
ARTICLE INFO \\
\hline Article History: \\
Received 09.09.2017 \\
Received in revised form \\
12.11 .2017 \\
Accepted \\
Available online 01.01 .2018
\end{tabular}

\begin{abstract}
The implementation of CIRC learning is expected to inc rease the ac ademic achievement in biology of pre-service elementary school teachers. Cooperative learning is based on positive interdependency, face to face interaction, individual responsibility, communication between members in group and process evaluation in group. The research aimed to study the influence of $C I R C$ on academic achievement in biology in Course of Basic Concept of Biology for Elementary School. The research was conducted for one semester to all students of Primary School Teacher Education Prog ram in Faculty of Teacher Training and Education, Pakuan University, Indonesia consisted of 59 students. The research was quasi experiment with rando mize factor. Research variables consisted of learning model and academic achievement in biology. Indicators used in ac ademic achievement in biology referred to the cognitive domain of Bloom's Taxonomy level. Data used was the result of pretest and posttest of academic achievement in biology. Ancova and de scriptive data statistic were used as data analysis. Ancova test resulted in significance level of 0.000 less than alpha of 0.05 . It can be concluded that CIRC gave better influence on academic achievement in biology compare to conventional learning. It was suggested that lecturer and teacher could implement $C I R C$ to increase biology achievement. Active learning with CIRC is able to make students reconstruct biological material, thus the knowledge could be in long term memory.
\end{abstract}

CC 2018 IJERE. All rights resenved

Keywords:

CIRC, Academic Achievement, Biology Learning.

\section{INTRODUCTION}

For the last couple years, various researches in various countries revealed the potential of cooperative learning in learning process (Durukan, 2011; Gupta \& Ahuja, 2014a; Hossain \& Tarmizi, 2013; Tran, 2014; Yeni., et al, 2012). Cooperative learning is one of active learning models focusing on team work to solve problems (Evans, 2008; Huang., at al, 2014; Uzunboylu et al, 2009) and is conducted in structured to achieve learning objectives that proven to be effective in increasing academic achievement (Hossain \& Tarmizi, 2013) and skill to collaborate, cooperate, share and socialize (Gupta \& Ahuja, 2014b). Cooperative learning is a learning aim to maximize learning process of students in a small group either for the students or the group itself (Johnson et al., 1994). Cooperative learning principles consisted of: 1) positive interdependency , 2) face to face interaction, 3) individual responsibility, 4) communication between members of group/social skill, and 5) evaluation of group process (Johnson \& Johnson, 2009; Muraya \& Kimamo, 2011; Slavin, 2008). The educational system is the major means of transmitting the knowledge and the values of every society (Papaoikonomou, 2017). Innovative works can be achieved through cooperative learning (Bustami, 2017). Through the learning, students will learn how to interact, being responsible to their own learning process and the group's, as well as respect others' academic ability and give contribution to their peer's academic achievement (Laal \& Ghodsi, 2012). Principally, student's attitude and behavior will have influence on the learning success of others (Johnson \& Johnson, 2009). In various level of education, students learned through cooperative learning are able to increase their academic achievement (Beck \& Chizhik, 2008; Zain, et al., 2009).

Cooperative Integrated Reading and Composition (CIRC) learning is one of cooperative learning models. It is a learning model stressing on reading and writing activities (Slavin, 2008, Zubaidah \& Corebima, 2016). The learning process emphasizing students to train to be actively involved in learning process through reading, discussion, looking for the main concepts and rew rite them along with opinion and reflection (Gupta \& Ahuja, 2014a). Steps in CIRC learning are: a) students are grouped into several heterogeneous groups, b) each group reads an article or a reading, c) students rew rite the result of discussion on a w orksheet, d) each group displays or presents their result, and e) the best group is rew arded (Kessler, 1992).

\footnotetext{
${ }^{1}$ Corresponding e-mail: rizhalhendi@unj.ac.id, Biology Education Department, State University of Jakarta, Indonesia,

${ }^{2}$ Biology Education Department, State University of Malang, Indonesia
} 
The success of an education system largely depends on the quality of the teachers who plan and practice teaching and learning process (Duman \& Karagöz, 2016). Good ability in reading and writing is needed in order to become a science savvy person (Holliday, et al., 1994). Reading ability is used to analyze and evaluate a reading, whereas writing ability is needed to communicate it to others. Fur ther, Holliday., et al, (1994) stated that in science learning process, reading and w riting activities could function as a conceptual tool to help students to analyze, interpret and communicate scientific ideas. Agree with that, the learning process that focuses on reading activities should be in order to increase academic qualities to students, not only the activities within classroom are important but also the activities outside classroom are contributing significantly to their personality (Karaağaç, 2017).

CIRC has three element principles, i.e.: the relationship of basic activities, direct order in understanding reading, and integration between the art of language and writing (Calderon., et al, 1997; Slavin, 2008). Activities in CIRC learning train students to read individually or in group. Then, students will conduct discussion to do activities of predicting, asking question, writing, revising, identifying, knowing where the problem is and the solution from a reading or an article as well as other activities such as summarizing, adding vocabulary, spelling and understanding the reading (Durukan, 2011; Gupta \& Ahuja, 2014b). Some research results indicated that CIRC learning model is effective to increase academic achievement in biology (Jatmiko., et al, 2012; Ristanto, 2009; Sukiastini., et al, 2013).

Research on CIRC cooperative learning was applied in Course of Basic Concept of Biology for Elementary School. The course is a compulsory course that must be taken by students of Primary School Teacher Education Program, Pakuan University, Indonesia. The purpose of the course is for students make students understand the basic concept of Biology as their provision to teach biology to their students and to be able to apply it in their daily life. The basic concept of Biology for Elementary School consisted of materials of cell and cell division, the classification of organism, plants, animals and organ system of animals and plants. It is hoped that after learning the material, the academic achievement in biology will be increased.

Research Result (Ristanto., et al., 2015) indicated that the biology achievement of students in Primary School Teacher Education Program, Pakuan University, Indonesia was low; therefore, a learning design is needed to overcome the problem. One of the learning models expected to increase learning students achievement is CIRC. According to Laurence \& Vimala (2012), academic achievement is a measurement of knowledge gained by students indicated by test result as well as level, average and degree of learning result.

\section{Research Aims}

The research aimed to find out the influence of CIRC learning model on academic achievement in the Course of Basic Concept of Biology for Elementary School. Research hypothezed was that there is a significant influence of CIRC learning model and conventional learning model on the biology achievement

\section{METHOD}

Method used in the research was quasi experiment with pretest-posttest non-equivalent control group design (McMillan \& Schumacher, 2010). The independent variables were CIRC learning model and conventional model, whereas the dependent variable was academic achievement biology.

Table 1. Experimental Design of the Randomized Pretest - Postest Control Group

\begin{tabular}{ccc}
\hline Pretest & $\begin{array}{c}\text { Treatm } \\
\text { ent }\end{array}$ & Posttest \\
\hline $\mathrm{T}_{1}$ & $\mathrm{X}_{1}$ & $\mathrm{~T}_{2}$ \\
$\mathrm{~T}_{3}$ & $\mathrm{X}_{2}$ & $\mathrm{~T}_{4}$ \\
\hline
\end{tabular}

Note: $\mathrm{T}_{1,3}=$ Pretest, $\mathrm{T}_{2,4}=$ Posttest, $\mathrm{X}_{2}=\mathrm{CIRC}$ Learning and $\mathrm{X}_{4}=$ Conventional Learning

Population and Sample 
Research population was all students in the first semester of Primary School Teacher Education Program, Faculty of Teacher Training and Education, Pakuan University, Indonesia consisted of 300 students. The number of sample in the research was 59 students. Sampling was conducted randomly where statistical test of grouping test was previously conducted based on grade data when entering the college. It was conducted to validate the level of class equality. Next, random sampling w as conducted to determine one experimental group and one control group. Students in the experimental group were learned through CIRC, whereas students in control class were learned through conventional. Conventional learning is a common learning model implemented in the lecture of Course of Basic Concept of Biology for Elementary School.

\section{Data Collection Technique}

As a preliminary stage, lecture adaptation was conducted tow ard assignments to be done during the learning and instruments used during CIRC learning. The research was conducted for one semester and consisted of 8 (eight) subjects: (a) cell as the smallest structural and functional units, (b) cell reproduction, (c) diversity of organism, (d) invertebrate and vertebrate animals, and (e) various functions in animal I (digestive system, circulation system, respiratory system, and reproduction system), (f) various functions in animals II (homeostasis system, endocrine system, nervous system, and movement system), (g) various functions in plant I (tissue structure, organ, and reproduction in flowering plant), and (h) various functions in plant II (growth, development, and photosynthesis). In every lecture activity, observation was done regarding the implementation of CIRC syntax. Data was collected through the activity students' academic achievement test in the biology before and after the research. The instrument of the test was in the form of essay test referring to Bloom's taxonomy consisted of remember (C1), understand (C2), apply (C3), analyze (C4), evaluate (C5), and create (C6).

\section{Data Analysis}

Data was analyzed using descriptive statistical analysis to indicate the description or profile of academic achievement in biology of the students. The descriptive statistic value consisted the average of standard deviation with the highest and lowest average. Inferential statistic was conducted to test the hypothesis by using ANCOVA analysis in significance level of 5\%. Least significance difference (LSD) test was conducted if a significant influence was occurred. Inferential statistical analysis was conducted using SPSS version 18 for Windows, started with homogeneity test and normality test.

\section{FINDINGS}

The summary of ANCOVA test result on the influence of CIRC learning model on academic achievement in biology is presented in Table 2.

Table 2. Result of Ancova Test on the influence of CIRC learning on academic achievement in biology

\begin{tabular}{crrrrr}
\hline Source & $\begin{array}{c}\text { Type III Sum of } \\
\text { Squares }\end{array}$ & Df & $\begin{array}{c}\text { Mean } \\
\text { Square }\end{array}$ & F & \multicolumn{1}{c}{ Sig } \\
\hline Corrected Model & $16290,414^{\mathrm{a}}$ & 2 & 8145,207 & 194,949 &, 000 \\
$\quad$ Intercept & 2905,322 & 1 & 2905,322 & 69,537 &, 000 \\
$\quad$ Pretest & 362,336 & 1 & 362,336 & 8,672 &, 005 \\
Learning_Model & 15434,372 & 1 & 15434,372 & 369,409 &, 00 \\
$\quad$ Error & 2339,747 & 56 & 41,781 & & \\
$\quad$ Total & 185795,250 & 59 & & & \\
$\quad$ Corrected & 18630,161 & 58 & & & \\
Total & & & & & \\
\hline
\end{tabular}

a. R Squared $=, 874$ (Adjusted R Squared $=, 870$ )

Ancova test on the influence of learning model on biology academic achievement resulted in significance level of 0.000 or less than alpha of $0.05<0.05$. It can be concluded that there was an influence of 
learning model on academic achievement in biology. Next, LSD test was conducted and the result is presented in Table 3.

Table 3. Result of LSD Test on the Influence of Learning Model on academic achievement in biology

\begin{tabular}{|c|c|c|c|c|}
\hline \multirow{3}{*}{ Class } & \multicolumn{2}{|c|}{ Average } & \multirow{3}{*}{$\begin{array}{l}\text { Average } \\
\text { Corrected }\end{array}$} & \multirow{3}{*}{$\begin{array}{l}\text { Increa } \\
\text { se }\end{array}$} \\
\hline & Pr & Postt & & \\
\hline & etest & est & & \\
\hline Conventional & 22 & 37 & 36,52 & $66,00 \%$ \\
\hline CIRC learning Model & 19 & 69 & 69,38 & $265,16 \%$ \\
\hline
\end{tabular}

Based on the result of LSD test in Table 3, it can be seen that the academic achievement biology students in experimental class $w$ as significantly higher than those in conventional class. The difference in the increase of academic achievement in biology with CIRC learning is $199.16 \%$ higher than the conventional class.

\section{DISCUSSION}

Based on the result of LSD test, it can be seen that the average grade of posttest of academic achievement in biology in both classes was increasing. The increase in the average grade in CIRC learning model was $256.16 \%$, whereas in conventional learning was $66.00 \%$. The increase was due to the implementation of learning that in accordance with the learning steps. According to Sihwinedar (2015), the implementation of appropriate learning could support conducive learning climate thus students will have meaningful learning experience and in turn, it could develop their intellectual skill.

Result of observation indicated that CIRC learning was implemented well and consistent during the learning process. The success of the implementation of learning steps was influenced by pre-arranged planning. Good learning planning will be able to optimize academic achievement according to the determined learning competence and objectives (Bustami, 2017). Therefore, both classes, CIRC and conventional, had impact on the increase in the academic achievement in biology of students.

The influence of learning model implemented can be seen in the result of Ancova test. The result indicated that learning model implemented had significant influence on students' academic a chievement in biology. It means that there was a difference in the academic achievement in biology between students of Primary School Teacher Education Program who learned with CIRC learning model and those with conventional model. Further, the difference could also be seen in the percentage of increase in the average grade of academic achievement in biology. CIRC learning model had percentage of the increase of $199.16 \%$ that higher and significantly different than those of conventional class.

The research found that CIRC learning model class was more capable in increasing the academic achievement in biology of students than conventional class. Students of Primary School Teacher Education Program were more able to remember by stating materials in the course of Basic Concept of Biology for Elementary School. In addition, students in CIRC class were more able to understand, apply by giving argument, analyze by explaining the problems that occur, and create by predicting and giving ideas on the basic concepts of biology.

The research result was in line with various researches conducted by Jatmiko., et al (2012), Sukiastini., et al (2013) and Ristanto (2009). The result of those researches stated that CIRC learning model was more influential on the academic achievement in biology compare to conventional learning. CIRC learning had superior influence compare to conventional learning because the learning model has more advantages than the conventional.

The advantage of CIRC learning model lies on the characteristic of each learning steps. The steps direct students to learn in a heterogeneous group consisted of 4-5 people. Each member is responsible in the achievement of learning objectives by discussion to solve problems (Evans, 2008; Huang., et al, 2014; 
Uzunboylu \& Ercag, 2009) and train the skill to collaborate, cooperate, share and socialize (Gupta \& Ahuja, 2014a) through reading and writing activities (Gupta \& Ahuja, 2014b).

The implementation of CIRC learning directs students to be actively involved in looking for cases in an article relevant to the material being studied. The article is read and analyzed. Reading is a process to understand the meaning contained in a language (Zubaidah, 2014). Reading activity will develop cognitive process through its thinking ability. Vito (2004) stated that there was a close relationship between reading habit and academic achievement. Further, Corebima (2009) stated that students familiarized with reading activity will increase their understanding on material being studied.

CIRC learning process also gives opportunity to a group to share or discuss their analysis result to others. The activity allows students to exchange their knowledge. Therefore, students will have more experience and in turn, it will form better concept mastery. Discussion activity could also train the formation of elaborating-cognitive ability among students. Information will last longer if students involve in restructuring activity or cognitive elaboration of the material being studied (Slavin, 1995).

In addition to read, students in CIRC class are also trained to be responsible in their group to master the material being analyzed. The activity consists of discussion to determine important matters in a reading, bring up follow up question and reflect from the activity. Result of discussion is written on a worksheet and presented or discussed.

Through step of writing questions, students are faced with selection of questions. Beyer (1997) stated that bringing up question is one of common techniques used to teach thinking ability. Further, Kirbulut (2016) stated that the objective of learning is to train students to be able to think and control their own learning process. Therefore, learning that involving a series of questions such as CIRC learning model has potential to increase the ability to think and learning process. Thus, the academic achievement in biology of students in CIRC class was significantly high compare to control class. The last activity, rew arding the best group during learning activity, was a positive activity and it encourages competition to achieve learning objectives.

Those steps could develop the spirit of students to be actively involved in learning process. Active learning is able to make students reconstruct biological material, thus the knowledge could be in long term memory (Bustami, 2017). The consequence is the increase in the academic achievement of students in the Course of Basic Concept of Biology for Elementary School.

The advantages of CIRC learning model cannot be found in conventional learning. In conventional class, learning process has not empowered students to be involved actively in learning. Students listen more to the presentation of lecturer and sometimes they are given a chance to submit discussion material through question. Lecturer-centered learning process has potential to hamper thinking process and activity of students. The learning process with less involvement from students will lead to less meaningful learning thus material gained will be easily forgotten.

\section{CONCLUSION AND SUGGESTIONS}

Based on the results of statistical tests and discussion of this research concluded that CIRC learning model gave significant influence on the academic achievement in biology of students in Primary School Teacher Education Program, Pakuan University, Indonesia. The academic achievement biology students in experimental class $w$ as significantly higher than those in conventional class. The difference in the increase of academic achievement in biology with CIRC learning is $199.16 \%$ higher than the conventional class. Based on the results of these studies, there are several suggestions for further research. a more in-depth analysis of the effectiveness of CIRC in biology-related learning on literacy skills, both in scientific literacy and reading literacy in the biological context. In addition, a further study of CIRC learning on biology studies in primary and secondary school students should be undertaken.

\section{REFERENCES}

Beck, L. L. \& Chizhik, A. W. (2008). An experimental study of cooperative learning in CS1. In Proceedings of the 39th SIGCSE technical symposium on Computer science education: 205-209. New York: ACM. 
Beyer, B. K. (1997). Improving Student Thinking: a Comprehensive Approach. Boston: Allyn and Bacon.

Bustami, Y. (2017). Pengaruh Strategi Pembelajaran Jirqa terhadap kemampuan kognitif, keterampilan berpikir kritis, dan sikap sosial mahasiswa multietnis pada perkuliahan zoologi di STKIP Persada Khatulistiwa. Unpublish Doctoral Disertation. Malang: Universitas Negeri Malang.

Calderon, M., Hertz-Lazarowitz, M., Ivory, G., \& Slavin, R.E. (1997). Effects of bilingual cooperative integrated reading and composition on students transitioning from spanish to english reading. Retrieved 16, May 2017 from: files.eric.ed.gov/fulltext/ED405428.pdf

Corebima, A.D. (2009). Jadikan peserta didik pebelajar mandiri. Seminar Nasional Pendidikan; 2009 Dec; Makassar, Indonesia. Universitas Negeri Makassar

Duman, T \& Karagöz, S. (2016). An evaluation of turkish teacher education system compared to other models in different countries. International Journal of Educational Research Review 1(1): 1-13

Durukan, E. (2011). Effects of cooperative integrated reading and composition (circ) technique on readingwriting skills. Educational Research and Reviews 6(1): 102-109.

Evans, C. (2008). The effectiveness of M-learning in the form of podcast revision lectures in higher education. Comuters \& Education, 50(2): 491-498.

Gupta, M \& Ahuja, J. (2014a). Cooperative integrated reading composition (circ): impact on reading comprehension achievement in english among seventh graders. IMPACT: International Journal of Research in Humanities, Arts and Literature 2(5): 37-46

Gupta, M \& Ahuja, J. (2014b). Effect of co-operative learning strategy (circ) on english reading. International Educational E-Journal, 3(1): 14-27.

Holliday, W.G., Yore, L.D., \& Alvermann, D.E. (1994). The reading-science learning writing connection: Breakthroughs, barriers, and promises. Journal of Research in Science Teaching, 31: 877-893.

Hossain, A \& Tarmizi, R.A. (2013). Effects of cooperative learning on students' achievement and attitudes in secondary mathematics. Procedia - Social and Behavioral Sciences 93: $473-477$.

Huang, Y.M., Liao, Y.W., Huang.S.H., \& Chen, H.C. (2014). A jigsaw -based cooperative learning. Educational Technology \& Society, 17(1): 128-140.

Jatmiko, A., Maridi., \& Aryanto, A. (2013). Penerapan model pembelajaran kooperatif tipe circ (cooperative integrated reading and composition) disertai media komik biologi untuk meningkatan minat belajar siswa dalam pelajaran biologi pada siswa kelas vii-a smp negeri 14 surakarta tahun pelajaran 2011/2012. Jurnal Pendidikan Biologi, 51: 15-25.

Johnson, DW; Johnson, RT., Stanne, MB \& Holubec, JE. (1994). Cooperative Learning in the Classroom. Virginia: Association for Supervision and Curriculum Development.

Johnson, D.W. \& Johnson, R.T. (2009). An educational psychology success story: social interdependence theory and cooperative learning. Journal of Educational researcher, 38(5): 365-379.

Karaağaç, P. (2017). Teachers' views on activities practised in elementary schools. International Journal of Educational Research Review, 2(1): 34-40.

Kessler, C. 1992. Cooperative Language Learning. New Jersey: Prentice Hall Regents.

Kirbulut, Z.D. (2016). Development of a metaconceptual awareness and regulation scale. International Journal of Science Education, 38(13): 2152-2173.

Laal, M \& Ghodsi, S, M. (2012). Benefits of collaborative learning. Procedia - Social and Behavioral Sciences 31: $486-490$.

Law rence, A.S.A., \& Vimala. (2012). School environment and academic achievement of standard ix Students. Journal of Educational and Instructional Studies in the World, 2(3): 210-215. 
McMillan, J.H. \& Schumacher, S. (2010). Research in Education: Evidence-based Inquiry. (7th Edition). London: Pearson.

Muraya, D.N \& Kimamo, G. (2011). Effects of cooperative learning approach on biology mean achievement scores of secondary school students' in machakos district, kenya. Educational Research and Reviews 6(12): 726-745.

Papaoikonomou, A. (2017). The impact of political socialization on students' behavior: empirical research in schools of Central Macedonia in Greece. International Journal of Educational Research Review, 2(2): 1-10.

Ristanto, R.H. (2009). Implementasi model pembelajaran kooperatif tipe circ cooperative integrated reading and composition) untuk meningkatkan hasil belajar biologi kelas xi ipa i "topik gangguan sistem transportasi pada manusia" sma negeri 1 sambungmacan, sragen tahun ajaran 2008/2009. Thesis unpublish. Surakarta: Universitas Muhammadiyah Surakarta.

Ristanto, R.H., Zubaidah, S., Amin, M., \& Rohman, F. (2015). An analysis of biology achievement based on gender and previous school major of the students of primary school teacher education at pakuan university. $8^{\text {th }}$ International Conference on Science, Mathematic Technology and Education, 2015 November 21-24; Sari Pan Pacific Hotel, Jakarta, Indonesia.

Sihwinedar, R. (2015). Meningkatkan hasil belajar IPA melalui penerapan model Pembelajan SAVI (Somatis, Auditori, Visual, dan Intelektual) pada siswa kelas III SDN Rejoagung 01 Semboro Tahun pelajaran 2013/2014. Jurnal Pancaran Pendidikan, 4(4): 137-148

Slavin, R.E. (1995). Cooperative Learning Theory, Research and Practice. Boston: United States of America.

Slavin, R.E. (2008). Cooperative Learning (Teori, Riset dan Praktik). Bandung: Nusa Media

Sukiastini, I G. A. N. K., Sadia, I.W., \& Suatra, I.W. (2013). Pengaruh model pembelajaran cooperative integrated reading and composition terhadap kemampuan pemecahan masalah dan berpikir kreatif. e-Journal Program Pascasarjana Universitas Pendidikan Ganesha, 3: 1-11.

Tran, D.V. (2014). The effects of cooperative learning on the academic achievement and knowledge retention. International Journal of Higher Education 3(2): 131-140.

Uzunboylu, H., Cavus, N., \& Ercag. (2009). Using mobile learning to increase environmental awarness. Computers E Education, 52(2): 381-389.

Yeni, L.F., Yekhebed., \& Khalsum, U. (2012). Efektivitas model pembelajaran cooperative integr ated reading and composition (circ) terhadap hasil belajar siswa pada sub materi pencemaran lingkungan di kelas x sma negeri 4 pontianak. Jurnal Visi Ilmu Pendidikan, 8(2): 803-814.

Zain, Z. M., Subramaniam, G., Rashid, A. A., \& Ghani, E. K. (2009). Teaching Students' Performance and Attitude. Canadian Social Science, 5(6): 92-102.

Zubaidah, S. 2014. Pemberdayaan keterampilan penemuan dalam scientific aprproach melalui pembelajaran berbasis remap coople. Prosiding Seminar Biologi 11(1): 1000-1011.

Zubaidah, S \& Corebima, D.A. (2016). Remap Coople (Reading-Concept Map-Cooperative Learning). Malang: Aditya Media Publishing 